\title{
Practical Applications of the Understanding of Foreign Cultures in Japanese-language Teachings
}

\author{
Junjie Xing* \\ Dalian Jiaotong University, Dalian 116203, Liaoning Province, China \\ *Corresponding author: Junjie Xing, starhero1017@163.com
}

\begin{abstract}
Due to differences in cultural patterns, backgrounds, and thinking styles, it is difficult to learn foreign languages. By integrating the understanding of foreign culture into Japanese-language teachings, students may be able to use Japanese in a more standardized manner based on the understanding of Japanese culture; hence, improving their Japanese proficiency. This article explored the practical strategies of understanding foreign cultures in Japanese-language teachings in hope of helping students improve their Japanese proficiency.
\end{abstract}

Keywords: Foreign cultures understanding; Japanese-language teaching; Practical strategies

Publication date: June 2021; Online publication: June 30, 2021

\section{Introduction}

Foreign cultures are also known as comparative cultures. In recent years, as economic globalization continues to accelerate, foreign cultures have gained much more attention. Many experts and scholars have conducted research while achieving results on different cultures and Japanese-language teachings. However, most of them included comparative academic research on one of the modules of a certain language. There are relatively few applied research about integrating the understanding of foreign cultures into Japaneselanguage teachings. Considering the characteristics of the subject as well as the students, it is necessary to examine the practical applications of foreign culture understandings in Japanese honorifics, greetings, and social language.

\section{Practical application of the understanding of foreign cultures in Japanese honorifics}

Individuals who have learned Japanese would easily understand Japanese honorifics as a simple language that defines the relationship between people such as superiors and subordinates. In fact, this is not the case. In the contemporary use of Japanese honorifics, it functions as a tool to measure the closeness in relationships between individuals. It is also used as a language tool to express the speakers' status or selfcultivation. For example, a Japanese person would generally say, “私は田中君のことを知っているほど には，恵美さんのことは存じ上げておりません” in his or her speech when witnessing a marriage of a younger generation. In this sentence, honorific expressions are used out of varying degrees of respect for the married couple. It is easy to appreciate the close relationship between the witness and the wife, Emi in this sentence. An analysis of the application of Japanese honorifics in business is shown in Table 1. 
Table 1. Analysis of the application of Japanese honorifics in business

\begin{tabular}{|l|l|}
\hline \multicolumn{1}{|c|}{ Japanese } & \multicolumn{1}{c|}{ Analysis of the use of honorifics } \\
\hline 部長は, 来週東京へ出張されますか & Honorific words are used in a dialogue between subordinates and ministers. \\
\hline 部長は, 東京へ出張しております & $\begin{array}{l}\text { Modest words are used as the subordinate is speaking about the minister to other } \\
\text { individuals excluding the company’s personnel. }\end{array}$ \\
\hline
\end{tabular}

The application of Japanese honorifics in business fully exemplifies the characteristic differences in Japanese language expressions inside and outside of the company which conveys group consciousness among the Japanese. ${ }^{[1]}$ When there are conflicts between the upper and lower-level staffs in companies and between staffs inside and outside companies, priority is usually given to deal with these internal and external conflicts. In the process of Japanese-language teachings, schools should not merely make use of commonly used examples in English sentences that express the relationship between superiors and subordinates while asking students to recite them. Instead, schools should integrate their teachings with the Japanese corporate culture while purposefully and consciously evaluating them in order to train students in understanding the Japanese's thinking styles.

Although Japanese people would be displeased to entertain salesman, they would still use honorifics when they refuse to buy items from them such as, “うちにはお金がありませんから，お帰りください.” The use of honorifics in this sentence does not imply that the speaker expresses his respect to the salesman but to indicate a distance between them. In this way, it fully expresses the speaker's status and education level.

The use of Japanese honorifics is actually very complicated. In addition to the use of these honorifics mentioned above, its' use is also closely related to gender, the psychological aspects of the speaker, and the contents of the speech.

\section{Practical applications of the understanding of foreign cultures in Japanese greetings}

Japanese greetings are essential components in Japanese-language teachings. However, in actual use, due to differences in cultural backgrounds, social customs, etc., they are prone to be misused or may form communication barriers. Most of the time, the reason for these mistakes in using Japanese greetings is the influence of the speakers' native language thinking patterns. In the process of teaching, teachers noticed that some students have difficulties in expressing their responses fluently when they are learning the language such as “はい.”[2] This is a relatively simple response but students are still not fluent in their expression. The main reason for this issue lies in the impediment of cultural backgrounds which leads to psychological barriers among students. In films with the anti-Japanese theme, there are scenes in which Japanese people would nod and bow while saying “はい.” The integration of foreign culture understandings while teaching Japanese greetings encourages students to correctly use these greetings, overcome the influence of preconceived views, and eliminate psychological barriers. Hence, teachers need to assist students to understand Japanese cultures as well as the characters' background, psychology, social relations, and occasions when “はい” is used. Common Japanese greetings or Teineigo are shown in Table 2. 
Table 2. Common Japanese greetings or Teineigo

\begin{tabular}{|l|l|}
\hline \multicolumn{1}{|c|}{ Common Japanese greetings or Teineigo } & Translation \\
\hline くれぐれも風邪を引かないようにお気をつけください & Please be careful not to catch a cold. \\
\hline 車に轢かれないように気をつけてください & Be careful not to be hit by a car. \\
\hline
\end{tabular}

However, these two sentences are usually not used in the Chinese's greetings or instructions. In view of China's social culture and its nation's psychology, these somewhat tabooed things are mentioned widely in Japan. The Japanese would discuss and predict life and death matters, diseases, disasters, etc. in a relatively calm manner. For example, Japanese people would watch reports on TV programs showing various situations about major earthquake occurrences and the harm caused by volcanic eruptions. On the other hand, people in China are more comfortable to look back at history instead. For example, after the great disaster of Tangshan Earthquake, the movie "Tangshan Earthquake" was then filmed. The Japanese chooses to face disasters head-on. This was manifested in the filming of "The Sinking of Japan" which displayed their calmness and direct confrontation in facing disasters. It is not possible to evaluate which of these country's social culture is better. Social culture itself is neither good or bad. ${ }^{[3]}$ Simply, different social and cultural backgrounds lead to different principles and philosophies of life. Hence, it is important for teachers to integrate the understanding of different cultures into Japanese-language teachings. Eventually, when students have a deep understanding of Japanese cultures, they would be able to competently use the Japanese language.

\section{Practical applications of the understanding of foreign cultures in Japanese social language}

There are many expressions of apologetic terms in the Japanese language and the ones that appear frequently in textbooks are, “申し訳ない,”“すみません,”“ごめん,” etc. Due to the cultural differences between China and Japan, the use of apologies varies. For the Japanese, it has strict regulations whereby an individual should not only use appropriate apologetic terms but he or she also needs to physically act out according to the degree of apology that is wished to be expressed. ${ }^{[4]}$ For example, if a person looks down, they need to be serious while their eyes and attitude would need to show sincerity. On the other hand, when expressing deep apologies, they would need to sit and bow while touching their hands to the ground. However, this is not the case in China. When individuals express their apologies, they would usually pat each other's backs, shoulders, or even shake hands to express their close relationship or to avoid awkward situations. Sometimes, they even express their apologies in a joking manner.

The Japanese have a stronger sense of gratitude and respect for others. When receiving sympathy, care, or patronage, they would express their gratitude in a serious manner. The commonly used terms in expressing gratitude are shown in Table 3. 
Table 3. Commonly used terms in expressing gratitude

\begin{tabular}{|l|l|}
\hline \multicolumn{1}{|c|}{ Commonly used terms in expressing gratitude } & \multicolumn{1}{c|}{ Specific use } \\
\hline $\begin{array}{l}\text { どうも，ありがとう，ありがとうございます，すみませ } \\
\text { ん, 失礼します }\end{array}$ & In the expression of general gratitude. \\
\hline 心から感謝いたします, 御礼を申し上げます & In the expression of a higher degree of gratitude. \\
\hline $\begin{array}{l}\text { お礼の言葉もございません,なんとお礼を申したらい } \\
\text { いか分かりません，誠に感謝にたえません }\end{array}$ & When receiving enormous help from others. \\
\hline 心から感謝いたします, 御礼を申し上げます & In formal occasions and more often in letters. \\
\hline
\end{tabular}

\section{Conclusion}

In summary, teachers need to realize that differences in social and cultural backgrounds are one of the main reasons that students are unable to flexibly use the Japanese language. By strengthening the understanding of foreign cultures and urging students to appreciate Japanese cultures in depth, students can then accurately grasp the connotations and the standard use of the Japanese language. Therefore, when students use the Japanese language to communicate with others, they would not encounter communication barriers or misunderstandings due to cultural differences which is extremely beneficial to the improvement of their Japanese proficiency.

\section{Disclosure statement}

The author declares no conflict of interest.

\section{References}

[1] Ma K, 2021, Thoughts on the teaching reform of the "Basic Japanese" course based on the TEM-4 in Japanese. Science and Education Wenhui, (04): 189-90.

[2] Huang H, 2021, "Basic Japanese" teaching reform and practice based on improving college students' autonomous learning ability. Public Relations World, (03): 86-7.

[3] Zheng D, 2021, Research on the strategies of stimulating learning interests in "teaching style to change study style" - An example of college Japanese classroom teaching reform. Knowledge Library, (07): 118-9.

[4] Yang X, 2021, Research on the integration of Chinese traditional cultural education in Japanese teaching - Comment on "Higher Japanese Education". Forest Products Industry, 58(03): 118. 